NASA/TM—2012-217418

\title{
Further Evaluation of Scaling Methods for Rotorcraft Icing
}

Jen-Ching Tsao

Ohio Aerospace Institute, Brook Park, Ohio

Richard E. Kreeger

Glenn Research Center, Cleveland, Ohio 


\section{NASA STI Program . . . in Profile}

Since its founding, NASA has been dedicated to the advancement of aeronautics and space science. The NASA Scientific and Technical Information (STI) program plays a key part in helping NASA maintain this important role.

The NASA STI Program operates under the auspices of the Agency Chief Information Officer. It collects, organizes, provides for archiving, and disseminates NASA's STI. The NASA STI program provides access to the NASA Aeronautics and Space Database and its public interface, the NASA Technical Reports Server, thus providing one of the largest collections of aeronautical and space science STI in the world. Results are published in both non-NASA channels and by NASA in the NASA STI Report Series, which includes the following report types:

- TECHNICAL PUBLICATION. Reports of completed research or a major significant phase of research that present the results of NASA programs and include extensive data or theoretical analysis. Includes compilations of significant scientific and technical data and information deemed to be of continuing reference value. NASA counterpart of peer-reviewed formal professional papers but has less stringent limitations on manuscript length and extent of graphic presentations.

- TECHNICAL MEMORANDUM. Scientific and technical findings that are preliminary or of specialized interest, e.g., quick release reports, working papers, and bibliographies that contain minimal annotation. Does not contain extensive analysis.

- CONTRACTOR REPORT. Scientific and technical findings by NASA-sponsored contractors and grantees.
- CONFERENCE PUBLICATION. Collected papers from scientific and technical conferences, symposia, seminars, or other meetings sponsored or cosponsored by NASA.

- SPECIAL PUBLICATION. Scientific, technical, or historical information from NASA programs, projects, and missions, often concerned with subjects having substantial public interest.

- TECHNICAL TRANSLATION. Englishlanguage translations of foreign scientific and technical material pertinent to NASA's mission.

Specialized services also include creating custom thesauri, building customized databases, organizing and publishing research results.

For more information about the NASA STI program, see the following:

- Access the NASA STI program home page at http://www.sti.nasa.gov

- E-mail your question via the Internet to help@ sti.nasa.gov

- Fax your question to the NASA STI Help Desk at $443-757-5803$

- Telephone the NASA STI Help Desk at 443-757-5802

- Write to: NASA Center for AeroSpace Information (CASI) 7115 Standard Drive Hanover, MD 21076-1320 
NASA/TM-2012-217418

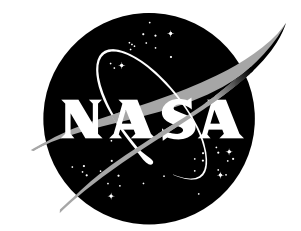

\section{Further Evaluation of Scaling Methods for Rotorcraft Icing}

Jen-Ching Tsao

Ohio Aerospace Institute, Brook Park, Ohio

Richard E. Kreeger

Glenn Research Center, Cleveland, Ohio

Prepared for the

International Conference on Aircraft and Engine Icing and Ground Deicing sponsored by the SAE International

Chicago, Illinois, June 13-17, 2011

National Aeronautics and

Space Administration

Glenn Research Center

Cleveland, Ohio 44135 


\section{Acknowledgments}

The authors acknowledge the support of the Subsonic Rotary Wing project under Fundamental Aeronautics at NASA Glenn Research Center. The authors also wish to thank the NASA Glenn Icing Research Tunnel (IRT) personnel for their excellent and committed technical support.

Trade names and trademarks are used in this report for identification only. Their usage does not constitute an official endorsement, either expressed or implied, by the National Aeronautics and Space Administration.

This work was sponsored by the Fundamental Aeronautics Program at the NASA Glenn Research Center.

Level of Review: This material has been technically reviewed by technical management.

Available from

NASA Center for Aerospace Information 7115 Standard Drive

Hanover, MD 21076-1320
National Technical Information Service 5301 Shawnee Road Alexandria, VA 22312 


\title{
Further Evaluation of Scaling Methods for Rotorcraft Icing
}

\author{
Jen-Ching Tsao \\ Ohio Aerospace Institute \\ Brook Park, Ohio 44142 \\ Richard E. Kreeger \\ National Aeronautics and Space Administration \\ Glenn Research Center \\ Cleveland, Ohio 44135
}

\begin{abstract}
The paper will present experimental results from two recent icing tests in the NASA Glenn Icing Research Tunnel (IRT). The first test, conducted in February 2009, was to evaluate the current recommended scaling methods for fixed wing (Refs. 1 and 2) on representative rotor airfoils at fixed angle of attack. For this test, scaling was based on the modified Ruff method with scale velocity determined by constant Weber number and water film Weber number. Models were un-swept NACA 0012 wing sections. The reference model had a chord of $91.4 \mathrm{~cm}$ and scale model had a chord of $35.6 \mathrm{~cm}$. Reference tests were conducted with velocity of $100 \mathrm{kt}(52 \mathrm{~m} / \mathrm{s})$, droplet medium volume diameter (MVD) $195 \mu \mathrm{m}$, and stagnation-point freezing fractions of 0.3 and 0.5 at angle of attack of $5^{\circ}$ and $7^{\circ}$. It was shown that good ice shape scaling was achieved with constant Weber number for NACA 0012 airfoils with angle of attack up to $7^{\circ}$. The second test, completed in May 2010, was primarily focused on obtaining transient and steady-state iced aerodynamics, ice accretion and shedding, and thermal icing validation data from an oscillating airfoil section over some selected ranges of icing conditions and blade assembly operational configurations. The model used was a 38.1-cm chord Sikorsky SC2110 airfoil section installed on an airfoil test apparatus with oscillating capability in the IRT. For two test conditions, size and condition scaling were performed. It was shown that good ice shape scaling was achieved for SC2110 airfoil at dynamic pitching motion. The data obtained will be applicable for future main rotor blade and tail rotor blade applications.
\end{abstract}

\section{Introduction}

Aircraft and component manufacturers must thoroughly test new products to determine the effect of icing on their performance. This testing is performed both during the design process and for certification purposes. Flight-testing is necessary but expensive and can only be done when atmospheric icing conditions exist. Furthermore, it can be very time consuming to find in nature the extremes in the cloud drop size and liquid-water content (LWC) envelope required for certification testing. Icing wind tunnels can simulate natural icing with water-spray and refrigeration systems and provide control of cloud conditions, temperature and airspeed to permit safe, convenient and relatively inexpensive testing. Because of test-section blockage limitations, many components cannot be tested full size in an icing wind tunnel. Furthermore, facilities that simulate natural icing can provide only limited ranges of air speed, cloud drop size, and LWC. An icing scaling method is a procedure to determine the scaled test conditions to produce the same non-dimensional ice shape results as exposing the reference model to the desired cloud conditions. When the reference (full-size) model is too large for a given facility, model-size scaling is applied, and when the desired test conditions are outside the facility operating capability, test-condition scaling is required. Constraints may also prohibit strict geometric scaling of sub-scale models.

Scaling methods consist of a set of equations that are used to determine the necessary scale test conditions, given the reference conditions, model size, and geometry that need to be simulated. Unlike the fixed-wing case where extensive research efforts to develop appropriate scaling methods (Refs. 1 and 2) 
have begun as early as in the 1950's and continue to the present, there is no single method that has been systematically developed and evaluated for rotorcraft icing scaling applications. The scaling parameters have not been adequately verified (Ref. 3), in part because there is no publicly available research-quality database with which to assess the validity of these methods in a rigorous manner. Scaling methodologies also play an important role in obtaining data for icing code development and validation (Ref. 4).

Previously, icing tests were performed in the NASA Glenn Icing Research Tunnel and scaling results for $0^{\circ}$ and $5^{\circ}$ angles of attack were presented by Tsao and Kreeger (Ref. 5). Evidence from ice-shape comparison has shown that for NACA 0012 airfoils the ability to simulate a reference ice shape by scaling was not affected by the angle of attack in the range tested. Also, for the limited conditions of this study, there was no evidence of any difference in the fundamental formation mechanisms of either feather growth or horn formation on airfoil models at finite angle of attack. However these tests were made with velocities of 76 and $100 \mathrm{kt}$, and these conclusions may not be valid for higher velocities. Similar concern for larger static angle of attack should also be considered. Recently, two icing test programs were conducted in the IRT to help identify the limiting conditions and to evaluate other potential alternatives of scaling methods for such application to improve the current scaling knowledge and capability for rotorcraft icing.

The test (1) was a follow-up study of Reference 5 in which the static angle of attack of NACA 0012 airfoil models was further extended from $5^{\circ}$ to $7^{\circ}$. Also in the study another potential scaling parameter, $\mathrm{We}_{f}$, was evaluated for velocity scaling in super-cooled large droplet (SLD) glaze icing conditions. The test (2), conducted in collaboration with Sikorsky, Boeing, Bell Helicopters, and the Georgia Institute of Technology, was a detailed aerodynamic, ice accretion and thermal icing study of oscillating SC2110 airfoils in various icing conditions. Size and condition scaling were performed for two selected cases (Ref. 6), NRC Run 453 and NRC Run 585 as reference conditions. The resulting ice shapes and some corresponding load measurements (lift, drag, and pitching moment) will be briefly compared with data from Reference 6 to provide a quick check on the current scaling method capability in applications to rotorcraft icing.

\section{Nomenclature}

$\begin{array}{ll}A_{c} & \text { Accumulation parameter, dimensionless } \\ \mathrm{c} & \text { Airfoil chord, } \mathrm{cm} . \\ d & \text { Cylinder diameter or } 2 \times \text { leading-edge radius of airfoil, } \mathrm{cm} \\ h_{c} & \text { Convective heat transfer coefficient, } \mathrm{cal} / \mathrm{sec}^{2} \mathrm{~K} \\ h_{G} & \text { Gas-phase mass-transfer coefficient, } \mathrm{g} / \mathrm{sec} \mathrm{m}^{2} \\ K & \text { Inertia parameter, dimensionless } \\ K_{0} & \text { Modified inertia parameter, dimensionless } \\ L & \text { Length proportional to model chord, } \mathrm{cm} . \\ \mathrm{LWC} & \text { Cloud liquid-water content, } \mathrm{g} / \mathrm{m}^{3} \\ \mathrm{MVD} & \text { Water droplet median volume diameter, } \mu \mathrm{m} \\ n_{0} & \text { Stagnation-point freezing fraction, dimensionless } \\ p & \text { Pressure, Pa } \\ p_{w} & \text { Vapor pressure of water in atmosphere, Pa } \\ p_{w w} & \text { Vapor pressure of water at the icing surface, Pa } \\ \mathrm{Re}_{\delta} & \text { Reynolds number of water drop, dimensionless } \\ t & \text { Temperature, }{ }^{\circ} \mathrm{C} \\ t_{f} & \text { Freezing temperature, }{ }^{\circ} \mathrm{C} \\ t_{s} & \text { Surface temperature, }{ }^{\circ} \mathrm{C}\end{array}$




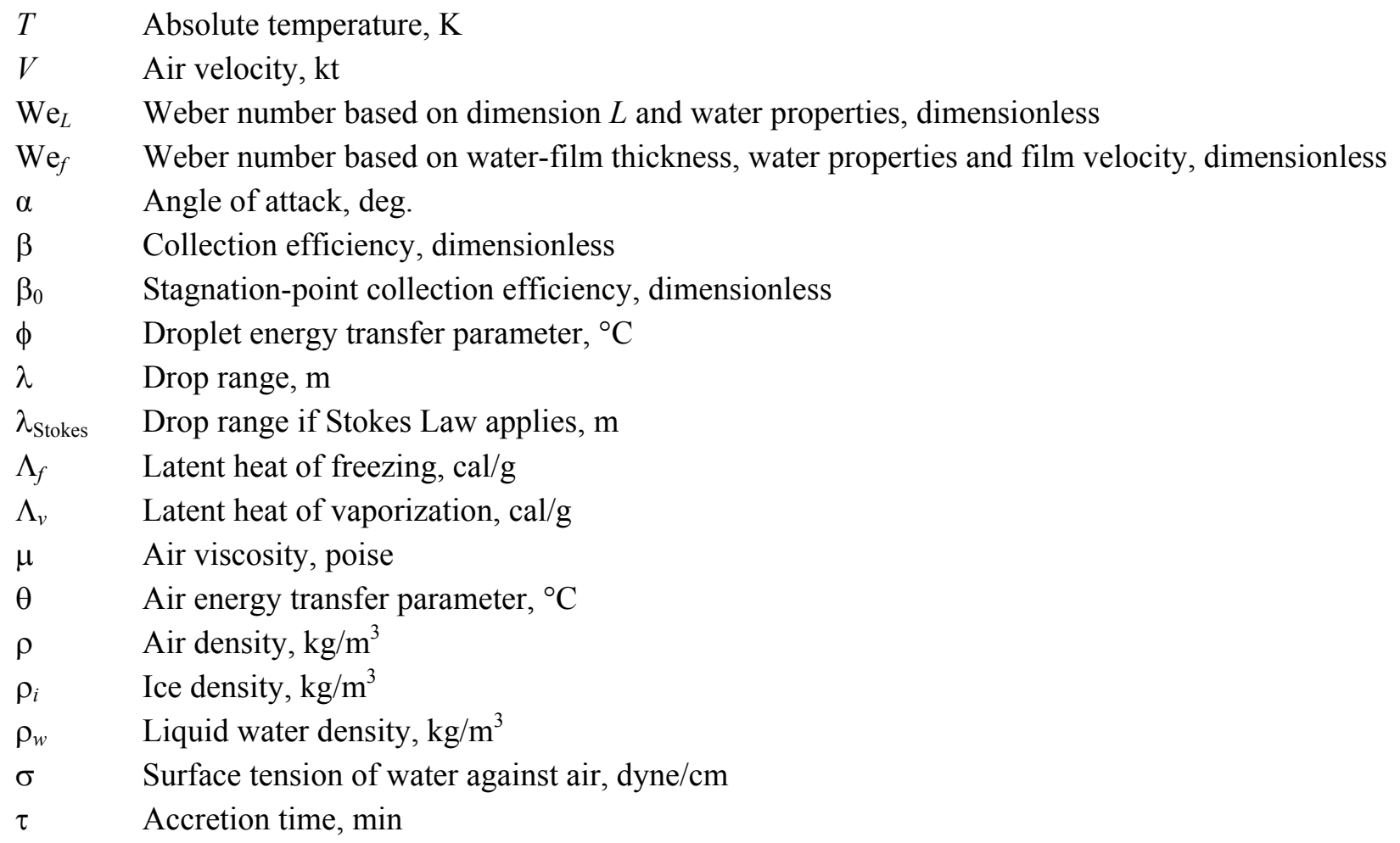

Subscripts:

$R \quad$ Reference

$S \quad$ Scale

st $\quad$ static

tot total

\section{Similarity Parameters}

The current recommended scaling methods (Refs. 1 and 2) for unprotected surfaces on fixed wings under Appendix C and SLD icing conditions would be a good candidate to begin the development of scaling method for rotorcraft icing study. These two references provide a detailed explanation of the rationale and derivations of the equations used to describe the similarity parameters involved in traditional fixed-wing aircraft icing. It also includes some validation data. A very brief summary of current understanding and practice of scaling methods is given here, and the reader is referred to these references for a more comprehensive discussion.

For traditional fixed-wing aircraft icing, various icing scaling studies over the past 50 years have shown that there are four most important similarity parameters affecting ice shape. They are:

(1) Accumulation parameter

$$
A_{c}=\frac{\mathrm{LWC} \mathrm{V} \tau}{d \rho_{i}}
$$


(2) Stagnation-point collection efficiency $\beta_{0}$, for example Langmuir and Blodgett (Ref. 7) had shown the $\beta_{0}$ for small water drops across a cylinder of radius $d$ to be a function only of the modified inertia parameter, $K_{0}$,

$$
\beta_{0}=\frac{1.40\left(K_{0}-\frac{1}{8}\right)^{0.84}}{1+1.40\left(K_{0}-\frac{1}{8}\right)^{0.84}}
$$

This $K_{0}$ was defined by Langmuir and Blodgett to describe the inertia of drops in an air stream flowing around a body:

$$
K_{0}=\frac{1}{8}+\frac{\lambda}{\lambda_{\text {Stokes }}}\left(K-\frac{1}{8}\right)
$$

In Equation (3), $K$ is the drop inertia parameter,

$$
K=\frac{\rho_{w} \operatorname{MVD}^{2} V}{18 d \mu}
$$

where $d$ is the radius for cylindrical models or twice the leading-edge radius for airfoils. Also in Equation (3) $\lambda / \lambda_{\text {Stokes }}$ is the drop range parameter, defined as the ratio of actual drop range to that if Stokes drag law for solid spheres applied. It is a function only of the drop Reynolds number, $\mathrm{Re}_{\delta}$.

$$
\operatorname{Re}_{\delta}=\frac{V \operatorname{MVD} \rho}{\mu}
$$

Langmuir and Blodgett tabulated the values of their calculated range parameter. For convenience, those data had been curve-fitted to the following expression:

$$
\frac{\lambda}{\lambda \text { Stokes }}=\left(\begin{array}{l}
0.8388+0.001483 \mathrm{Re}_{\delta} \\
+0.1847 \sqrt{\mathrm{Re}_{\delta}}
\end{array}\right)^{-1}
$$

(3) Stagnation-point freezing fraction, $n_{0}$. From Messinger's (Ref. 8) surface energy balance, the stagnation-point freezing fraction is

$$
n_{0}=\frac{c_{p, w s}}{\Lambda_{f}}\left(\phi+\frac{\theta}{b_{0}}\right)
$$

The individual terms in this expression are $\phi$, the water energy transfer parameter,

$$
\varphi=t_{f}-t_{\mathrm{st}}-\frac{V^{2}}{2 c_{p, w s}}
$$


$\theta$, the air energy transfer parameter,

$$
\theta=\left(t_{\mathrm{s}}-t_{\mathrm{st}}-r \frac{V^{2}}{2 c_{p}}\right)+\frac{h_{G}}{h_{c}}\left(\frac{\frac{p_{w w}}{T_{\mathrm{st}}}-\frac{p_{\mathrm{tot}}}{T_{\mathrm{tot}}} \frac{p_{w}}{p_{\mathrm{st}}}}{\frac{1}{.622} \frac{p_{\mathrm{tot}}}{T_{\mathrm{tot}}}-\frac{p_{w w}}{T_{\mathrm{st}}}}\right) \Lambda_{v}
$$

and $b_{0}$, the relative heat factor, introduced by Tribus, et al., (Ref. 9) At the stagnation line, it is:

$$
b_{0}=\frac{\operatorname{LWC} V \beta_{0} c_{p, w s}}{h_{c}}
$$

Equation Error! Reference source not found. from Ruff (Ref. 10) includes compressibility effects. A simpler form without compressibility was used by Charpin and Fasso (Ref. 11) and others. Ruff's expression for $\theta$ was used in the calculations for all this work, but values found without compressibility are not significantly different for most icing conditions.

(4) Weber number

$$
\mathrm{We}_{L}=\frac{V^{2} d \rho_{w}}{\sigma}
$$

With scale model size selected, by matching scale and reference values of $\mathrm{We}_{L}$ the scale velocity can be determined from

$$
V_{S}=V_{R}\left(\frac{d_{R}}{d_{S}}\right)^{1 / 2}
$$

Another approach presented by Feo (Ref. 12) involved matching simultaneously the water-film thickness and a Weber number that used the water-film velocity and water-film thickness:

$$
\mathrm{We}_{f}=\frac{V_{f}^{2} h_{f} \rho_{w}}{\sigma}
$$

By equating shear stresses at the air-water interface, the water-film velocity can be written as

$$
V_{f}=\operatorname{Re}^{1 / 2}\left(\frac{h_{f}}{d}\right) V
$$

When Equation (12) is substituted into Equation (11) and letting scale and reference values of $\left(h_{f} / d\right)$ be equated while matching $\mathrm{We}_{f, S}=\mathrm{We}_{f, R}$, the expression becomes

$$
\left(\operatorname{ReWe}_{L}\right)_{S}=\left(\operatorname{ReWe}_{L}\right)_{R}
$$

From Equation (13) the scale velocity from the constant $\mathrm{We}_{f}$ method is 


$$
V_{S}=V_{R}\left(\frac{d_{R}}{d_{S}}\right)^{2 / 3}
$$

By matching $\beta_{0}$ the scale MVD can be found. References 1 and 2 also showed that the effects of temperature and LWC are not independent, but interact through the freezing fraction. This is effectively the conceptual base of the Olsen method (Ref. 13) for condition scaling. With scale LWC (or temperature) selected by user, the scale temperature (or LWC) can be calculated by matching $n_{0}$. Finally the scale time can be established by matching $A_{c}$. For the scale model test, then, only temperature (or LWC), velocity, MVD and time have to be calculated from the known (reference) values of the similarity parameters.

While some of those similarity parameters are based on conditions that apply anywhere on the model, $\beta_{0}$ and $n_{0}$ are specific to the stagnation line of a clean model. Therefore, strictly speaking, scaling methods only apply at the stagnation line of a clean model. These parameters vary with chord-wise location and change as ice accretion modifies the geometry. Consequently, two assumptions are implied for scaling to be valid. The first is that with similar model geometries and similar flows around both reference and scale models, if $\beta$ and $n$ match at the stagnation point, they will tend to match everywhere on the model. This assumption has been verified for collection efficiencies in Reference 2. As for other airflow related issues: transition and roughness, for example, may not scale, and Re effects are assumed to have a minor influence on the final ice shape. Second, if the scaling is done successfully, the scale ice shape normalized by the model size will consistently agree with the reference for any accretion time starting with the clean model. Thus, scale $\beta$ and $n$ will continue to match the respective reference values, even though those parameters are changing with time.

As for rotorcraft all the similarity considerations for fixed-wing aircraft icing should apply. In addition, compressibility and dynamic effects due to blade rotation must be considered. Also flow-field similarity requires matching of advance ratio and pitching settings as well as geometric similarity of the rotors. While future studies need to demonstrate scaling when aforementioned effects are present, it is necessary for the development of the appropriate scaling methods to begin with a much simplified flow and model configuration as a baseline and proceed with additional physical effect of importance one at a time in testing. This could allow us to evaluate the significance of various physical effects unique to rotorcraft icing independently and reduces the complications from scaling testing.

Therefore we begin with the main rotor to address scaling, and the baseline is a two-dimensional flow over a generic rotor blade airfoil at a prescribed angle of attack that can simulate local flow conditions along the blade at various radial locations. In test (1), the symmetrical NACA 0012 airfoil models of different chord size were used. The prescribed angle of attack is fixed in time. However in test (2) an oscillating SC2110 airfoil section was used with a range of oscillation amplitude and frequency for unsteady angle of attack simulation.

\section{Test Description}

The icing tests were performed in the NASA Glenn Icing Research Tunnel (IRT). The IRT is a closed-loop, refrigerated, sea-level tunnel with a 1.8 by $2.7 \mathrm{~m}$ rectangular test section. The icing cloud is generated by operating 10 spray bars, a configuration in use since 1998. The IRT cloud calibrations for both Appendix-C and SLD conditions used for test (1) were performed in the summer of 2008. The LWC measurements were made using icing blade method as reported previously (Ref. 14). The MVDs reported in this paper are based on an analysis of the MVD calibration data completed in February, 2006. In addition, because only a few specific MVD-LWC combinations at speeds of 100, 150, 200, and $250 \mathrm{kt}$ $(51,77,103$, and $128 \mathrm{~m} / \mathrm{s})$ have been calibrated to date in the SLD regime, additional LWC measurements for SLD conditions were made in the IRT on September 22, 2008 with an icing blade. Therefore SLD tests are constrained to these particular conditions. As for test (2), the IRT cloud calibrations for both Appendix-C and SLD conditions used were performed in April 2009. 


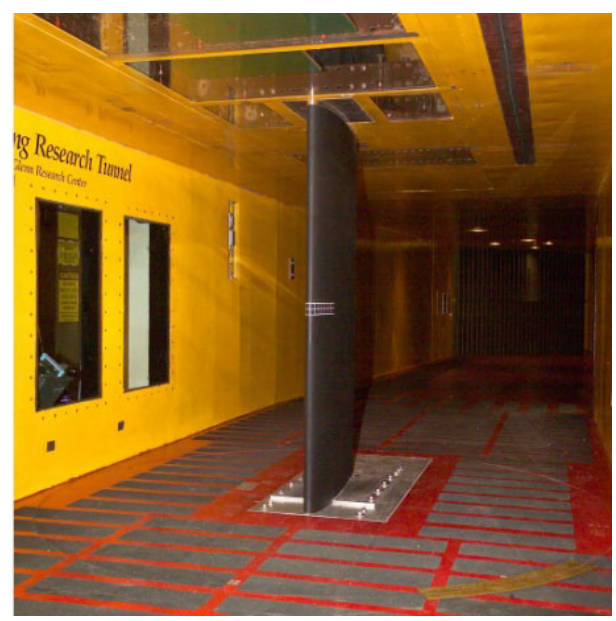

91.4-cm-chord full-span reference model

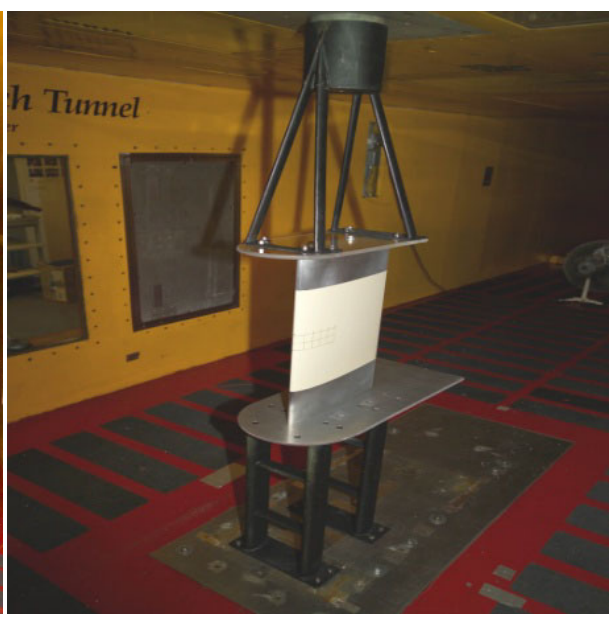

35.6-cm-chord 61-cm-span scale model

Figure 1.-NACA 0012 models installed in IRT test section.

\section{Test 1: NACA 0012 Airfoils at Fixed Angle of Attack in Glaze Icing}

In February 2009, a 5-day test entry was conducted in the NASA Glenn Icing Research Tunnel to examine currently existing scaling methods on rotor blades at larger angles of attack. The scaling methods were applied to NACA 0012 airfoil models at angle of $5^{\circ}$ and $7^{\circ}$ through icing conditions that covers a range of MVD's, air speeds and LWC's, i.e., a number of stagnation-point freezing fractions.

The models used were NACA 0012 airfoil sections with chords of 91.4 and $35.6 \mathrm{~cm}$ shown in Figure 1. The 91.4-cm-chord airfoil was a full-span, fiberglass model and served as the reference model. The 35.6-cm-chord scale model was of $61-\mathrm{cm}$ span and made of aluminum. It was mounted vertically between splitter plates at the center of the IRT test section. The supports allow changing the angle of attack via IRT turntable control. Although no angle-of-attack sweeps are planned for this test, models need to be rotated to align with airflow using external pressure belts wrapped around the model leading edge at specified chord-wise locations along the tunnel vertical center plane. For AOA of $5^{\circ}$ and $7^{\circ}$ both reference and scale models were rotated to align with the airflow by matching the corresponding $c_{p}$ curve using the external pressure taps on the models. Horizontal lines at the leading edge indicated tunnel center and $\pm 2.5 \mathrm{~cm}$ from the center as visual guides for locating ice tracings. Both SLD and Mod-1 nozzles were used. Also because of the quick start capability of the current IRT spray system, the models were not shielded during the initiation of the spray.

\section{Test 2: An Oscillating SC2110 Airfoil in Icing}

In May 2010, a 10-day test entry of an oscillating rotorcraft airfoil was completed in the IRT. The model used was a pressure and thermally instrumented helicopter airfoil section of 38.1-cm chord shown in Figure 2. The main objective of this test was to obtain ice accretion and detailed aerodynamic measurements for two-dimensional clean and iced oscillating airfoils undergoing both steady and transient behavior. It should be noted that the IRT has made some change on nozzle arrangement during the April 2009 calibration. As a result, SLD clouds were generated by Mod-1 nozzles.

In preparing for a test, the temperature and airspeed in the test section and the air and water pressures on the spray manifolds were set. When these conditions had stabilized, the spray nozzle valves were opened to initiate the spray. The spray was timed for the required duration, and then turned off. The fan was brought to a full stop and the researchers entered the test section to document the ice shape with hand tracings. Close-up photographs were also taken with a hand-held digital camera. To record the ice shapes, a thin slice was first melted through the ice normal to the model surface. A cardboard template was then 


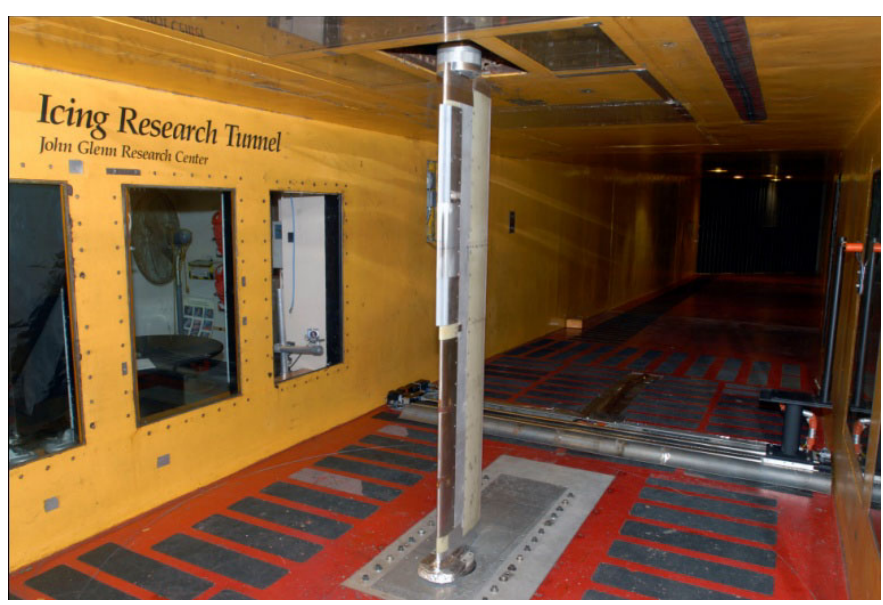

Figure 2.-Sikorsky SC2110 model installed in IRT test section.

placed into this slit and an outline of the ice shape traced by pencil, giving a two-dimensional cross section of the ice. For test (1), tracings were taken at the vertical center of the tunnel $(91 \mathrm{~cm}$ from the floor) and at $2.5 \mathrm{~cm}$ above the center. For test (2), tracings were taken at stations of 71.1 and $121.9 \mathrm{~cm}$ from the floor. The ice shapes so recorded were digitized using an automated line-following feature in the image-analysis software, SigmaScan Pro (Ref. 15). Since the ice shape differences between the two tracing locations were not significant for test (1), only centerline shapes will be reported. As for test (2), the $121.9-\mathrm{cm}$ station ice shapes will be reported.

\section{Uncertainty Analysis}

Estimates of the uncertainty in the reported average conditions were made by considering inherent errors of instruments, temporal fluctuation and spatial variation of the instrument readings in the test section, and uncertainty in tunnel calibration of MVD and LWC. Recorded air temperature was believed to be accurate to $\pm 0.2^{\circ} \mathrm{C}$, although variations during the period of an icing spray increases the uncertainty for reported average temperatures to about $\pm 0.5^{\circ} \mathrm{C}$. The uncertainty in air velocity was estimated to be \pm 2 kt. For Appendix-C conditions the net uncertainty in MVD was estimated at \pm 12 percent. For SLD conditions it may have been as much as \pm 20 percent. These uncertainties are not referenced to an absolute value of MVD, which is unknown. Repeatability and scatter in the LWC calibration data suggests the uncertainty is about \pm 12 percent for both Appendix-C and SLD conditions. The test-parameter uncertainties were used to estimate the following uncertainties in the similarity parameters for the test (1) the uncertainties were: 2 percent in $\beta_{0}, 12$ percent in $A_{c}, 10$ percent in $n_{0}$ and 3 percent in $\mathrm{We}_{L}$ and for the test (2) the uncertainties were: 3 percent in $\beta_{0}, 12$ percent in $A_{c}, 13$ percent in $n_{0}$ and 2 percent in $\mathrm{We}_{L}$.

\section{Test Results}

\section{Test 1: NACA 0012 Airfoils at Fixed Angle of Attack in Glaze Icing}

In planning the test matrix, reference test conditions were chosen so that both reference and scale conditions would fall within the IRT operating envelope. Due to very limited IRT test time available for the scaling evaluation this study is only focused on the SLD droplets. A preliminary evaluation of two velocity scaling methods at finite angle of attack was shown in Figures 3 to 6 . Those figures compared the non-dimensional reference and scale ice shapes obtained using the constant $\mathrm{We}_{L}$ method (part (a) of each figure) with those using the constant $\mathrm{We}_{f}$ method (part (b) of each figure) at $\alpha=5^{\circ}$ and $7^{\circ}$, and for stagnation-point freezing fraction of 0.3 and 0.5 at reference velocities of $100 \mathrm{kt}$. For each figure, reference ice shape was shown shaded, while a solid line indicated the scale ice shape. 
(a) $\mathrm{We}_{L}=c$

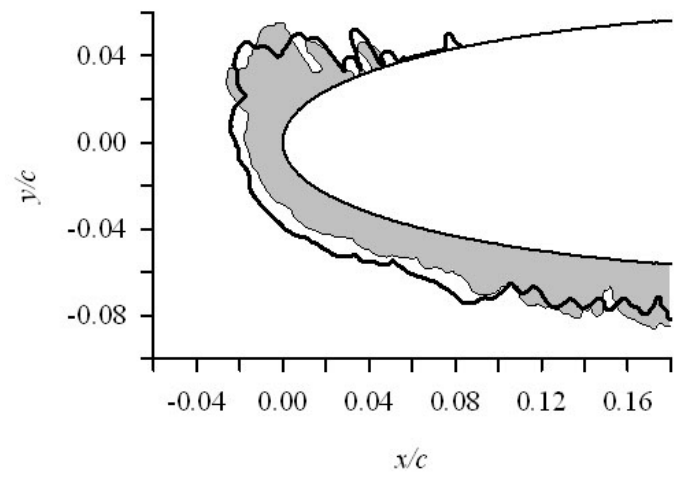

(b) $W e_{f}=c$

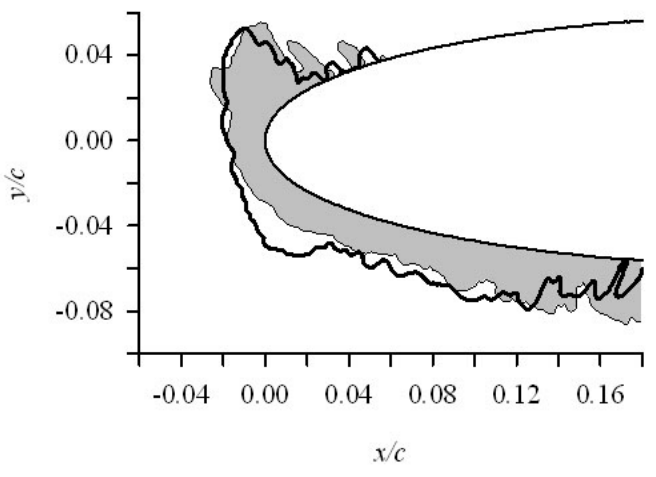

\begin{tabular}{|c|c|c|c|c|c|c|c|c|c|c|c|c|c|c|}
\hline & \multirow[b]{2}{*}{ Date/Run } & \multicolumn{7}{|c|}{$\begin{aligned} c & =91.4 \mathrm{~cm}, 02-03-09 \text { Run } 1 \\
c & =35.6 \mathrm{~cm}, 02-05-09 \text { Run } 6\end{aligned}$} & \multicolumn{6}{|c|}{$\begin{aligned} \Longleftarrow c & =91.4 \mathrm{~cm}, 02-03-09 \text { Run } 1 \\
& =35.6 \mathrm{~cm}, 02-05-09 \text { Run } 1\end{aligned}$} \\
\hline & & $\begin{array}{l}c, \\
\mathrm{~cm}\end{array}$ & $\begin{array}{l}t_{\mathrm{st}}, \\
{ }^{\circ} \mathrm{C}\end{array}$ & $\begin{array}{l}t_{\text {tot }}, \\
{ }^{\circ} \mathrm{C}\end{array}$ & $\begin{array}{l}V, \\
\mathrm{kt}\end{array}$ & $\begin{array}{c}\text { MVD, } \\
\mu \mathrm{m}\end{array}$ & $\begin{array}{l}\mathrm{LWC}, \\
\mathrm{g} / \mathrm{m}^{3}\end{array}$ & $\begin{array}{c}\tau, \\
\min \end{array}$ & $\begin{array}{c}\beta_{0}, \\
\text { percent }\end{array}$ & $A_{c}$ & $\beta_{0} A_{c}$ & $n_{0}$ & $\begin{array}{l}\mathrm{We}_{L}, \\
10^{6}\end{array}$ & $\begin{array}{l}\mathrm{We}_{f} \\
10^{-16}\end{array}$ \\
\hline \multirow[t]{2}{*}{ (a) } & $02-03-09 / 1$ & 91.4 & -9.1 & -7.8 & 100 & 199 & 1.08 & 14.0 & 96 & 1.75 & 1.68 & 0.31 & 1.17 & 0.74 \\
\hline & $02-05-09 / 6$ & 35.6 & -9.4 & -6.2 & 156 & 88 & 1.37 & 3.02 & 96 & 1.94 & 1.86 & 0.28 & 1.11 & 3.26 \\
\hline \multirow[t]{2}{*}{ (b) } & $02-03-09 / 1$ & 91.4 & -9.1 & -7.8 & 100 & 199 & 1.08 & 14.0 & 96 & 1.75 & 1.68 & 0.31 & 1.17 & 0.74 \\
\hline & $02-05-09 / 1$ & 35.6 & -7.1 & -2.6 & 186 & 86 & 0.54 & 5.61 & 96 & 1.68 & 1.62 & 0.31 & 1.57 & 0.72 \\
\hline
\end{tabular}

Figure 3.- Velocity scaling with $\mathrm{We}_{L}$ and $\mathrm{We}_{f}$ matched. NACA 0012 airfoils with $\alpha, 5^{\circ} ; n_{0}, 0.3 ; V_{R}, 100 \mathrm{kt}$.

(a) $\mathrm{We}_{L}=c$

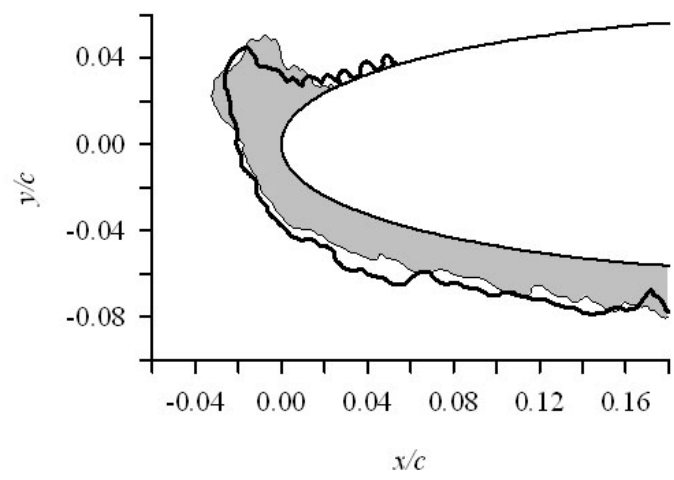

(b) $\mathrm{We}_{f}=c$

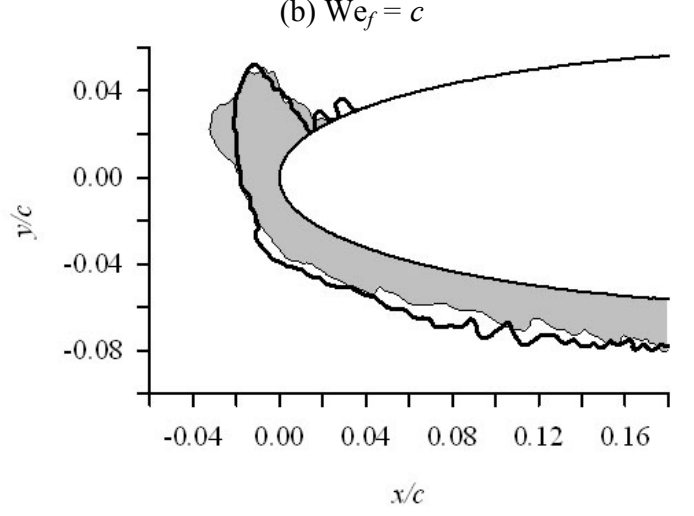

ए $c=91.4 \mathrm{~cm}, 02-04-09$ Run 1 - $c=35.6 \mathrm{~cm}, 02-06-09$ Run 1

ए $c=91.4 \mathrm{~cm}, 02-04-09$ Run 1

$\longrightarrow c=35.6 \mathrm{~cm}, 02-06-09$ Run 6

\begin{tabular}{|c|c|c|c|c|c|c|c|c|c|c|c|c|c|c|}
\hline & \multirow[b]{2}{*}{ Date/Run } & \multicolumn{6}{|c|}{$\begin{aligned} & c=91.4 \mathrm{~cm}, 02-04-09 \text { Run } 1 \\
\longrightarrow c & =35.6 \mathrm{~cm}, 02-06-09 \operatorname{Run} 6\end{aligned}$} & \multicolumn{7}{|c|}{$\begin{aligned}{ }_{c} & =91.4 \mathrm{~cm}, 02-04-09 \text { Run } 1 \\
& =35.6 \mathrm{~cm}, 02-06-09 \text { Run } 1\end{aligned}$} \\
\hline & & $\begin{array}{l}c, \\
\mathrm{~cm}\end{array}$ & ${ }^{t_{\mathrm{st}}}$ & $\begin{array}{l}t_{\text {tot }}, \\
{ }^{\circ} \mathrm{C}\end{array}$ & $\begin{array}{l}V, \\
\mathrm{kt}\end{array}$ & $\begin{array}{c}\text { MVD, } \\
\mu \mathrm{m}\end{array}$ & $\begin{array}{l}\text { LWC, } \\
\mathrm{g} / \mathrm{m}^{3}\end{array}$ & $\begin{array}{c}\tau, \\
\min \end{array}$ & $\begin{array}{c}\beta_{0} \\
\text { percent }\end{array}$ & $A_{c}$ & $\beta_{0} A_{c}$ & $n_{0}$ & $\begin{array}{l}\mathrm{We}_{L}, \\
10^{6}\end{array}$ & $\begin{array}{l}\mathrm{We}_{f}, \\
10^{-16}\end{array}$ \\
\hline \multirow[t]{2}{*}{ (a) } & $02-04-09 / 1$ & 91.4 & -9.1 & -7.8 & 99 & 198 & 1.08 & 14.0 & 96 & 1.74 & 1.67 & 0.31 & 1.16 & 0.75 \\
\hline & $02-06-09 / 6$ & 35.6 & -9.5 & -6.2 & 159 & 88 & 1.35 & 3.05 & 96 & 1.96 & 1.89 & 0.29 & 1.15 & 3.14 \\
\hline \multirow[t]{2}{*}{ (b) } & $02-04-09 / 1$ & 91.4 & -9.1 & -7.8 & 99 & 198 & 1.08 & 14.0 & 96 & 1.74 & 1.67 & 0.31 & 1.16 & 0.75 \\
\hline & $02-06-09 / 1$ & 35.6 & -7.3 & -2.7 & 188 & 86 & 0.53 & 5.65 & 96 & 1.68 & 1.62 & 0.32 & 1.61 & 0.70 \\
\hline
\end{tabular}

Figure 4.--Velocity scaling with $\mathrm{We}_{L}$ and $\mathrm{We}_{f}$ matched. NACA 0012 airfoils with $\alpha, 7^{\circ} ; n_{0}, 0.3 ; V_{R}, 100 \mathrm{kt}$. 
(a) $\mathrm{We}_{L}=c$

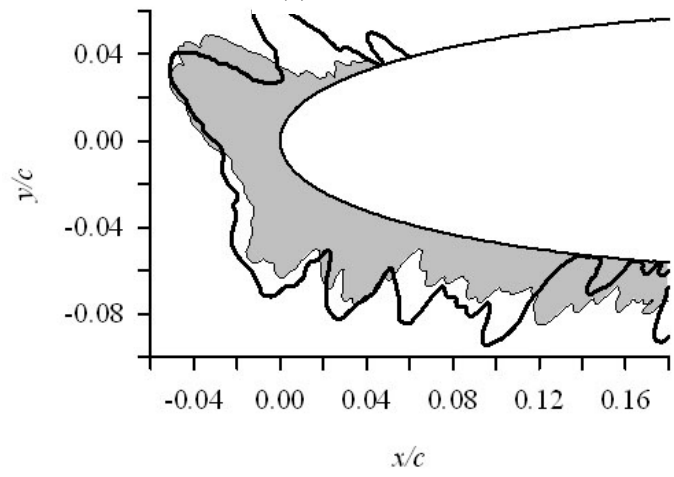

ए $c=91.4 \mathrm{~cm}, 02-03-09$ Run 3

- $c=35.6 \mathrm{~cm}, 02-05-09$ Run 8 (b) $\mathrm{We}_{f}=c$

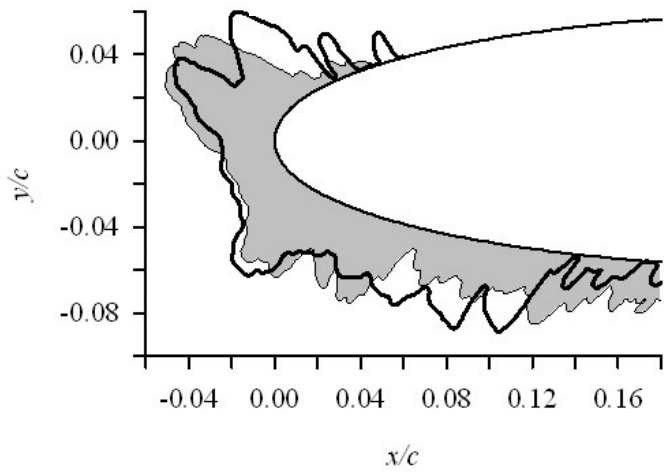

己 $c=91.4 \mathrm{~cm}, 02-03-09$ Run 3 $-c=35.6 \mathrm{~cm}, 02-05-09$ Run 5

\begin{tabular}{|c|c|c|c|c|c|c|c|c|c|c|c|c|c|c|}
\hline & Date/Run & $\begin{array}{c}c, \\
\mathrm{~cm}\end{array}$ & $\begin{array}{l}t_{\mathrm{st}}, \\
{ }^{\circ} \mathrm{C}\end{array}$ & ${ }^{t_{\text {tot }}}$, & $\begin{array}{l}V, \\
\mathrm{kt}\end{array}$ & $\begin{array}{c}\text { MVD, } \\
\mu \mathrm{m}\end{array}$ & $\begin{array}{c}\text { LWC, } \\
\mathrm{g} / \mathrm{m}^{3}\end{array}$ & $\begin{array}{c}\tau, \\
\min \end{array}$ & $\begin{array}{c}\beta_{0}, \\
\text { percent }\end{array}$ & $A_{c}$ & $\beta_{0} A_{c}$ & $n_{0}$ & $\begin{array}{c}\mathrm{We}_{L}, \\
10^{6}\end{array}$ & $\begin{array}{l}\mathrm{We}_{f} \\
10^{-16}\end{array}$ \\
\hline \multirow[t]{2}{*}{ (a) } & $02-03-09 / 3$ & 91.4 & -15.3 & -14.0 & 100 & 199 & 1.08 & 14.0 & 96 & 1.75 & 1.69 & 0.52 & 1.17 & 0.75 \\
\hline & $02-05-09 / 8$ & 35.6 & -15.9 & -12.3 & 159 & 88 & 1.31 & 2.90 & 96 & 1.81 & 1.74 & 0.51 & 1.16 & 3.04 \\
\hline \multirow[t]{2}{*}{ (b) } & $02-03-09 / 3$ & 91.4 & -15.3 & -14.0 & 100 & 199 & 1.08 & 14.0 & 96 & 1.75 & 1.69 & 0.52 & 1.17 & 0.75 \\
\hline & $02-05-09 / 5$ & 35.6 & -10.6 & -5.90 & 188 & 86 & 0.53 & 5.60 & 96 & 1.67 & 1.61 & 0.53 & 1.61 & 0.70 \\
\hline
\end{tabular}

Figure 5.-Velocity scaling with $\mathrm{We}_{L}$ and $\mathrm{We}_{f}$ matched. NACA 0012 airfoils with $\alpha, 5^{\circ} ; n_{0}, 0.5 ; V_{R}, 100 \mathrm{kt}$.

(a) $\mathrm{We}_{L}=c$

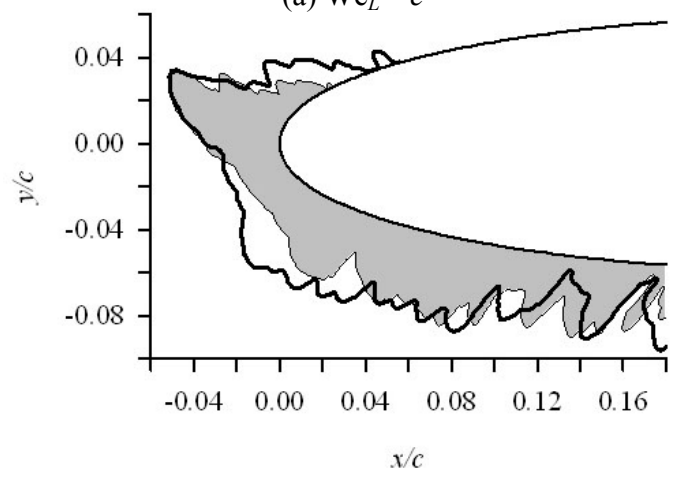

ए $c=91.4 \mathrm{~cm}, 02-04-09$ Run 3

$c=35.6 \mathrm{~cm}, 02-06-09$ Run 8 (b) $\mathrm{We}_{f}=c$

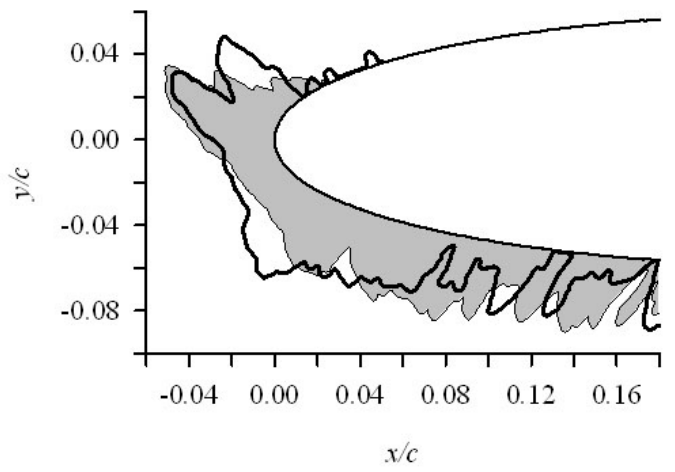

ए $c=91.4 \mathrm{~cm}, 02-04-09$ Run 3 $-c=35.6 \mathrm{~cm}, 02-06-09$ Run 5

\begin{tabular}{|c|c|c|c|c|c|c|c|c|c|c|c|c|c|c|}
\hline & Date/Run & $\begin{array}{c}c \\
\mathrm{~cm}\end{array}$ & $\begin{array}{l}t_{s t}, \\
{ }^{\circ} \mathrm{C}\end{array}$ & $\begin{array}{l}t_{\text {tot }}, \\
{ }^{\circ} \mathrm{C}\end{array}$ & $\begin{array}{l}V, \\
\mathrm{kt}\end{array}$ & $\begin{array}{c}\text { MVD, } \\
\mu \mathrm{m}\end{array}$ & $\begin{array}{c}\text { LWC, } \\
\mathrm{g} / \mathrm{m}^{3}\end{array}$ & $\begin{array}{c}\tau \\
\min \end{array}$ & $\begin{array}{c}\beta_{0}, \\
\text { percent }\end{array}$ & $A_{c}$ & $\beta_{0} A_{c}$ & $n_{0}$ & $\begin{array}{c}\mathrm{We}_{L}, \\
10^{6}\end{array}$ & $\begin{array}{l}\mathrm{We}_{f} \\
10^{-16}\end{array}$ \\
\hline \multirow[t]{2}{*}{ (a) } & $02-04-09 / 3$ & 91.4 & -15.3 & -14.0 & 100 & 198 & 1.08 & 14.0 & 96 & 1.75 & 1.68 & 0.52 & 1.16 & 0.76 \\
\hline & $02-06-09 / 8$ & 35.6 & -15.8 & -12.4 & 159 & 88 & 1.31 & 2.92 & 96 & 1.83 & 1.76 & 0.50 & 1.16 & 3.03 \\
\hline \multirow[t]{2}{*}{ (b) } & $02-04-09 / 3$ & 91.4 & -15.3 & -14.0 & 100 & 198 & 1.08 & 14.0 & 96 & 1.75 & 1.68 & 0.52 & 1.16 & 0.76 \\
\hline & $02-06-09 / 5$ & 35.6 & -10.5 & -5.9 & 188 & 86 & 0.53 & 5.64 & 96 & 1.68 & 1.62 & 0.53 & 1.61 & 0.70 \\
\hline
\end{tabular}

Figure 6.-Velocity scaling with $\mathrm{We}_{L}$ and $\mathrm{We}_{f}$ matched. NACA 0012 airfoils with $\alpha, 7^{\circ} ; n_{0}, 0.5 ; V_{R}, 100 \mathrm{kt}$. 
The table below each figure gave the test conditions and similarity parameters for each pair of reference and scale tests. The conditions given were the average conditions recorded over the duration of each test, which can sometimes differ slightly from the planned set points. The parameters in the tables were calculated from these average conditions.

Stagnation-Point Freezing Fraction of 0.3.-Figures 3 and 4 showed reference and scale ice shape comparisons for the constant $\mathrm{We}_{L}$ and constant $\mathrm{We}_{f}$ methods at $\alpha=5^{\circ}$ and $7^{\circ}$ respectively. The reference model size, velocity and MVD were $91.4 \mathrm{~cm}, 100 \mathrm{kt}$, and $195 \mu \mathrm{m}$. The scale model size was $35.6 \mathrm{~cm}$. The coordinates of the ice shapes were all normalized by the corresponding model chord.

In Figure 3(a) the scale and reference values of $\beta_{0}$ matched well but $A_{c}, \beta_{0} A_{c}$, and $n_{0}$ were just within 10 percent, and $\mathrm{We}_{L}$ matched within 5 percent. This was because the averaged reference LWC value was reduced to 94 percent of the planned value (i.e., $1.15 \mathrm{~g} / \mathrm{m}^{3}$ instead of $1.08 \mathrm{~g} / \mathrm{m}^{3}$ ) and the scale LWC was increased by 7 percent from its planned value (i.e., $1.28 \mathrm{~g} / \mathrm{m}^{3}$ instead of $1.37 \mathrm{~g} / \mathrm{m}^{3}$ ) based on the IRT calibration. This disagreement explains the difference observed in the leading-edge ice thickness for this pair of shapes. However the scale ice shape did closely simulate the reference main ice shape and feather region, even including smaller feathers further aft on the surface. In Figure 3(b) the scale and reference values of $\beta_{0}$ and $n_{0}$ matched well and $A_{c}, \beta_{0} A_{c}$, and $\mathrm{We}_{f}$ were also agreed within about 4 percent. The size of the reference ice was simulated fairly well by the scale test in the leading-edge region. The scale ice shape also captured pretty well the upper horn structure however it had a rather distinct lower horn structure that was not observed in the reference ice shape.

In Figure 4(a) the scale and reference values of $\beta_{0}$ and $\mathrm{We}_{L}$ matched well but $A_{c}$, and $\beta_{0} A_{c}$ were just within 12 percent, and $n_{0}$ matched within 6 percent. This was because the averaged reference $\mathrm{LWC}$ value was reduced to 94 percent of the planned value (i.e., $1.15 \mathrm{~g} / \mathrm{m}^{3}$ instead of $1.08 \mathrm{~g} / \mathrm{m}^{3}$ ) and the scale LWC was increased by 5 percent from its planned value (i.e., $1.28 \mathrm{~g} / \mathrm{m}^{3}$ instead of $1.35 \mathrm{~g} / \mathrm{m}^{3}$ ) based on the IRT calibration. This disagreement again explains the difference observed in the leading-edge ice thickness for this pair of shapes. However the scale ice shape captured the reference main ice shape and feather region fairly well except the scale upper horn was a bit thinner than the reference one has shown.

In Figure 4(b) the scale and reference values of $\beta_{0}$ matched well, $A_{c}, \beta_{0} A_{c}$, and $n_{0}$ were also agreed within about 3 percent, and $\mathrm{We}_{f}$ matched within 7 percent. The size of the reference ice was simulated fairly well by the scale test in the leading-edge region. The scale ice shape however did not simulate the overall reference horn structure very well.

Stagnation-Point Freezing Fraction of 0.5.-Figures 5 and 6 showed reference and scale ice shape comparisons for the constant $\mathrm{We}_{L}$ and constant $\mathrm{We}_{f}$ methods at $\alpha=5^{\circ}$ and $7^{\circ}$ respectively. In Figure 5(a) the scale and reference values of $\beta_{0}$ and $\mathrm{We}_{L}$ matched well and $A_{c}, \beta_{0} A_{c}$, and $n_{0}$ were just within 3 percent. This was because the averaged reference LWC value was reduced to 94 percent of the planned value (i.e., $1.15 \mathrm{~g} / \mathrm{m}^{3}$ instead of $1.08 \mathrm{~g} / \mathrm{m}^{3}$ ) and the scale LWC was reduced by 2 percent from its planned value (i.e., $1.34 \mathrm{~g} / \mathrm{m}^{3}$ instead of $1.31 \mathrm{~g} / \mathrm{m}^{3}$ ) based on the IRT calibration. This difference might explain the overall size of the scale ice shape appears to be a bit larger than the reference. Still the scale ice shape did simulate the reference main ice shape and the feathers well, though a few large feathers in the aft region of scale ice shape were not observed in the reference ice shape.

In Figure 5(b) the scale and reference values of $\beta_{0}$ matched well and $\left(A_{c}, \beta_{0} A_{c}\right), n_{0}$ and $W e_{f}$ were also agreed within about 5,2, and 7 percent respectively. This was because the averaged reference LWC value was reduced to 94 percent of the planned value (i.e., $1.15 \mathrm{~g} / \mathrm{m}^{3}$ instead of $1.08 \mathrm{~g} / \mathrm{m}^{3}$ ) and the scale LWC was reduced by 10 percent from its planned value (i.e., $0.59 \mathrm{~g} / \mathrm{m}^{3}$ instead of $0.53 \mathrm{~g} / \mathrm{m}^{3}$ ) based on the IRT calibration. This difference might explain the overall size of the scale ice shape seems to be smaller than the reference. The scale ice shape captured the reference main ice shape fairly well, though the simulated upper horn structure appears to be smaller than the reference.

In Figure 6(a) the scale and reference values of $\beta_{0}$ and $\mathrm{We}_{L}$ matched well but $A_{c}$, and $\beta_{0} A_{c}$ were just within 6 percent, and $n_{0}$ matched within 4 percent. This was because the averaged reference LWC value was reduced to 94 percent of the planned value (i.e., $1.15 \mathrm{~g} / \mathrm{m}^{3}$ instead of $1.08 \mathrm{~g} / \mathrm{m}^{3}$ ) and the scale LWC was reduced by 2 percent from its planned value (i.e., $1.34 \mathrm{~g} / \mathrm{m}^{3}$ instead of $1.31 \mathrm{~g} / \mathrm{m}^{3}$ ) based on the IRT 
calibration. This disagreement might explain the difference observed in the leading-edge ice thickness for this pair of shapes and also why the overall size of the scale ice shape appears to be a bit larger than the reference. However the scale ice shape captured the reference main ice shape and feather region fairly well except in the lower horn area where the scale ice shape has a thicker structure than the reference one has shown.

In Figure 6(b) the scale and reference values of $\beta_{0}$ matched well, $A_{c}$ and $\beta_{0} A_{c}$ were also agreed within about 4 percent, $n_{0}$ matched within 2 percent, and $\mathrm{We}_{f}$ matched within 9 percent. This was because the averaged reference LWC value was reduced to 94 percent of the planned value (i.e., $1.15 \mathrm{~g} / \mathrm{m}^{3}$ instead of $1.08 \mathrm{~g} / \mathrm{m}^{3}$ ) and the scale LWC was reduced by 10 percent from its planned value (i.e., $0.59 \mathrm{~g} / \mathrm{m}^{3}$ instead of $0.53 \mathrm{~g} / \mathrm{m}^{3}$ ) based on the IRT calibration. This difference might explain the difference observed in the leading-edge ice thickness for this pair of shapes and also why the overall size of the scale ice shape seems to be smaller than the reference. The size of the reference ice was simulated fairly well by the scale test in the leading-edge region but the scale ice shape did not simulate the overall reference horn structure very well.

\section{Test 2: An Oscillating SC2110 Airfoil in Icing}

In planning the test matrix, there was consideration to run some icing conditions from previous rotor airfoil icing test and compare the results with data from Reference 6. Two cases, NRC Run 453 and NRC Run 585, were chosen as reference conditions. The model used for those conditions was a 15.2-cm-chord NACA 0012 airfoil but the present test utilized a Sikorsky SC2110 airfoil section of 38.1-cm chord.

Figure 7 showed the cross section profiles of both airfoils near the leading edge. In spite of the high-lift camber of SC2110 airfoil, both airfoils have rather similar leading edge characteristics in terms of their nose radius of curvature and maximum thickness to chord size ratios. Therefore it was decided that for calculating the scale test conditions the NACA 0012 airfoil of 35.6-cm chord was used as the scale model and the 15.2-cm-chord NACA 0012 airfoil as the reference model.

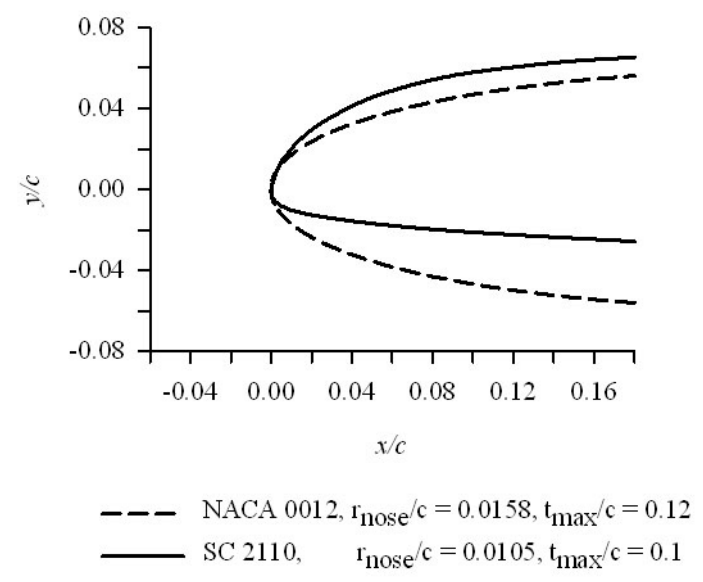

Figure 7.-NACA 0012 and SC2110 airfoil section profiles. 

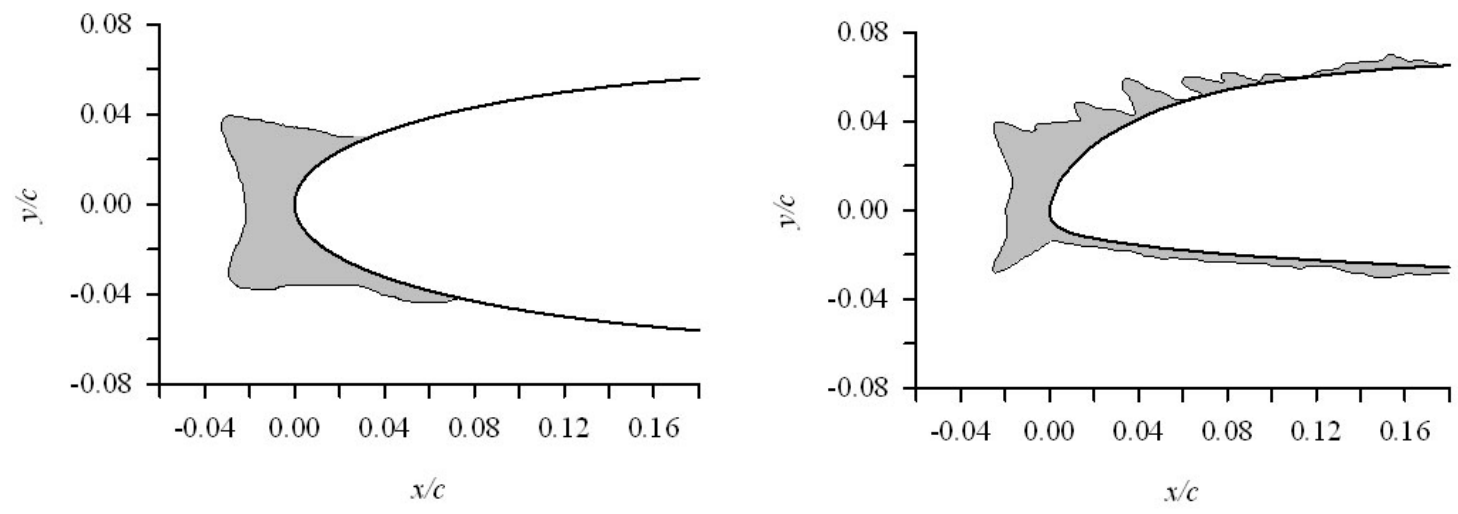

\begin{tabular}{|c|c|c|c|c|c|c|c|c|c|c|c|c|c|c|}
\hline & & $\square$ & $\mathrm{NRO}$ & $\operatorname{lin} 58$ & & & & & $\square$ & $05-27$ & 0 Run & & & \\
\hline Date/Run & $\begin{array}{c}c, \\
\mathrm{~cm}\end{array}$ & $M$ & $\begin{array}{l}t_{\text {tot, }} \\
{ }^{\circ} \mathrm{C}\end{array}$ & $\begin{array}{l}V, \\
\mathrm{kt}\end{array}$ & $\begin{array}{c}\text { MVD, } \\
\mu \mathrm{m}\end{array}$ & $\begin{array}{l}\text { LWC, } \\
\mathrm{g} / \mathrm{m}^{3}\end{array}$ & $\begin{array}{r}\tau, \\
\min \end{array}$ & $\begin{array}{c}\beta_{0}, \\
\text { percent }\end{array}$ & $A_{c}$ & $n_{0}$ & $\begin{array}{c}\mathrm{We}_{L}, \\
10^{6}\end{array}$ & $\begin{array}{c}\alpha, \\
\circ\end{array}$ & $\begin{array}{c}\Delta \alpha \\
0\end{array}$ & $\begin{array}{l}\omega, \\
H z\end{array}$ \\
\hline NRC Run 585 & 15.2 & 0.59 & -10. & 370 & 20 & 1.03 & 0.75 & 92 & 1.99 & 0.68 & 2.68 & -0.1 & 4.5 & 5 \\
\hline NRC Run $585 \mathrm{~m}$ & 15.2 & 0.40 & -10. & 250 & 20 & 1.03 & 0.75 & 91 & 1.35 & 0.66 & 1.23 & -0.1 & 4.5 & 5 \\
\hline 5-27-10 Run 60 & 38.1 & 0.25 & -9.2 & 158 & 43 & 0.65 & 4.70 & 91 & 1.35 & 0.66 & 1.23 & -0.1 & 4.5 & 5 \\
\hline
\end{tabular}

Figure 8.--Size scaling with $\mathrm{We}_{L}$ matched for NRC Run 585.

Condition Scaling for NRC Run 585.-Figure 8 showed reference and scale ice shape comparison for the case NRC Run 585 in which the airfoil was oscillating at $\alpha=-0.1^{\circ}$ with moderate amplitude and frequency. When calculating the scale condition, it was concerned that the scale velocity would be still high ( $\approx 235 \mathrm{kt}$ ) so the reference velocity was reset to $250 \mathrm{kt}$ (i.e., $M=0.4$ instead of 0.59 ) for calculation. Taking into account the potential velocity change effect on the reference ice shape, for instance some increase in horn angle and some reduction in the size of ice shape, the scale ice shape did simulate the reference main ice shape quite well. Distinctive feather regions on the scale ice shape were completely missed from the reference ice shape. It was very possible with such a short spray ( $45 \mathrm{sec}$ only) that the reference ice shape did not even have any large enough feathers behind the horns to be penciled in on the tracing templates. This is the difficulty and challenge often encountered in icing scaling study: i.e., "how good is good enough". Conceptually the scaling method should work for all scales in size and time but practically there is always limit on how much detail can be included. Therefore when reference and scale ice shape comparison was made one often needed to bear this in mind.

For this case, condition scaling methods were also applied to the 5-27-10 Run 60 to generate an alternative scaling condition in which the user can utilize better LWC and MVD values within the IRT operational envelope. It was previously reported in Reference 2 that the Olsen method can be used to scale LWC over a limited range at least in the IRT for both Appendix C and SLD condition. Furthermore if the scale test was only interested in simulating the main ice shape but not the icing limit; a recommended procedure for MVD scaling can be used as well over the range of 25 to $195 \mu \mathrm{m}$. Interested reader is referred to this reference for a more comprehensive discussion.

Figure 9 showed the reference and scale ice shapes obtained from aforementioned condition scaling calculations. The 5-27-10 Run 60 was considered as the reference and the 5-27-10 Run 59 as the scale condition. With a LWC of $0.5 \mathrm{~g} / \mathrm{m}^{3}$ and a MVD of $22 \mu \mathrm{m}$ while maintaining the velocity and model size the same, the temperature and spray time for the new scale condition were calculated by matching the reference $n_{0}$ and $\beta_{0} A c$. As expected with smaller MVD, the scale ice shape captured the reference main ice shape and large feathers on the upper surface fairly well. The only thing missed by the scale ice shape was the region of very small feathers covering most of the lower reference model surface. For this ice shape, the authors actually have examined the tracing templates and discovered that though there was no pencil tracing but a note was there describing about the very small feathers in that region. 


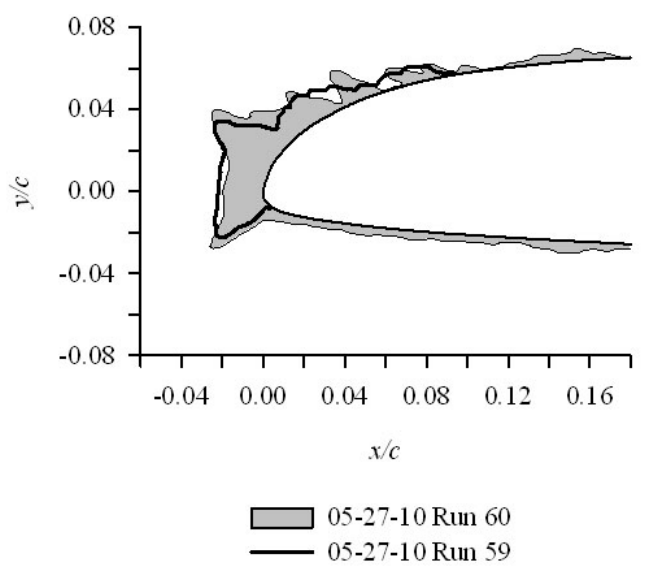

\begin{tabular}{|c|c|c|c|c|c|c|c|c|c|c|c|c|c|c|c|}
\hline Date/Run & $\begin{array}{l}c, \\
\mathrm{~cm}\end{array}$ & $M$ & ${ }^{t}$ tot, & $\begin{array}{l}V, \\
\mathrm{kt}\end{array}$ & $\begin{array}{c}\text { MVD, } \\
\mu \mathrm{m}\end{array}$ & $\begin{array}{l}\mathrm{LWC}, \\
\mathrm{g} / \mathrm{m}^{3}\end{array}$ & $\begin{array}{c}\tau, \\
\min \end{array}$ & $\begin{array}{c}\beta_{0}, \\
\text { percent }\end{array}$ & $A_{c}$ & $\beta_{0} A c$ & $n_{0}$ & $\begin{array}{c}\mathrm{We}_{L}, \\
10^{6}\end{array}$ & $\begin{array}{c}\alpha, \\
\circ\end{array}$ & $\underset{0}{\Delta \alpha}$ & $\begin{array}{l}\omega, \\
H z\end{array}$ \\
\hline 5-27-10 Run & 38.1 & 0.2 & -9.2 & 158 & 43 & 0.65 & 4.7 & 91 & 1.3 & 1.22 & 0 . & 1.23 & -0.1 & 4.5 & 5 \\
\hline 5-27-10 Run & 38.1 & 0.2 & -6.1 & 158 & 22 & 0.50 & 6.9 & 80 & 1.5 & 1.22 & 0 . & 1.23 & -0.1 & 4.5 & 5 \\
\hline
\end{tabular}

Figure 9.-LWC and MVD scaling application for 5-27-10 Run 60.

For icing scaling studies, it had never been able to obtain the aerodynamic load measurement and the ice accretion at the same time. The load measurements such as $C_{L}, C_{D}$, and $C_{M}$ certainly provided invaluable information on how airflow interacts with ice shape during the accretion. It helped one to assess how similar the iced aerodynamics was for the reference and scale ice shapes and how sensitive the aerodynamic responses to any discernible difference between the reference and the scale ice shape.

Figures 10 to 12 showed and compared the time history of $C_{L}, C_{D}$, and $C_{M}$ measurements for two geometrically similar ice shapes obtained from condition scaling, i.e., 5-27-10 Run 59 and 60. Although those load measurement were raw data and have not been properly reduced for detailed load analysis purpose, it was considered adequate for this study to help evaluate how aerodynamically similar those two ice shapes were. It was observed that:

1. Both $C_{L}$ and $C_{M}$ of the scale ice shape simulated fairly well the reference $C_{L}$ and $C_{M}$ curves. This implied the overall large scale reference ice shape features such as the main ice shape and large feathers were duplicated fairly well by the scale ice shape. Aerodynamically speaking, the inviscid air responses of these two ice shapes were similar.

2. The $C_{D}$ curve of the scale ice shape though followed the general trend of the reference $C_{D}$; it seemed to under represent the reference drag value. This suggested that the small ice shape features did matter to the overall drag through the interaction with the airflow boundary layer, and so far as the drag was concerned, the scale ice shape did not capture those smaller ice feathers of reference ice shape well enough to have similar drag characteristics.

These findings were consistent with the current understanding of the effect of various ice shape features on the ensuing aerodynamics of an iced airfoil.

Condition Scaling for NRC Run 453.-Figure 12 showed reference and scale ice shape comparison for the case NRC Run 453 in which the airfoil was oscillating at $\alpha=6^{\circ}$ with moderate amplitude and frequency. Size and condition scaling calculations were performed to determine the scale test conditions. Since this was a rime ice accretion, it permitted one to choose the scale $V$, LWC, and MVD, and the temperature and spray time were calculated by matching reference $n_{0}(=1)$ and $\beta_{0} A c$. Certainly the scale temperature could have gone colder than the value obtained from the scaling calculation for just rime. It was a good practice for the researchers to set the temperature just cold enough to have rime to 
independently validate the tunnel's LWC calibration. For any researcher to develop confidence in the tunnel operation capability, it was recommended to include some rime ice test conditions to check on the facility whenever possible.

Considering the apparent effect of model geometry on rime ice accretion, the scale rime ice shape of 5-26-10 Run 52 did simulate well the reference NRC Run 453 rime ice shape except the overall size appeared to be a bit smaller than the reference.

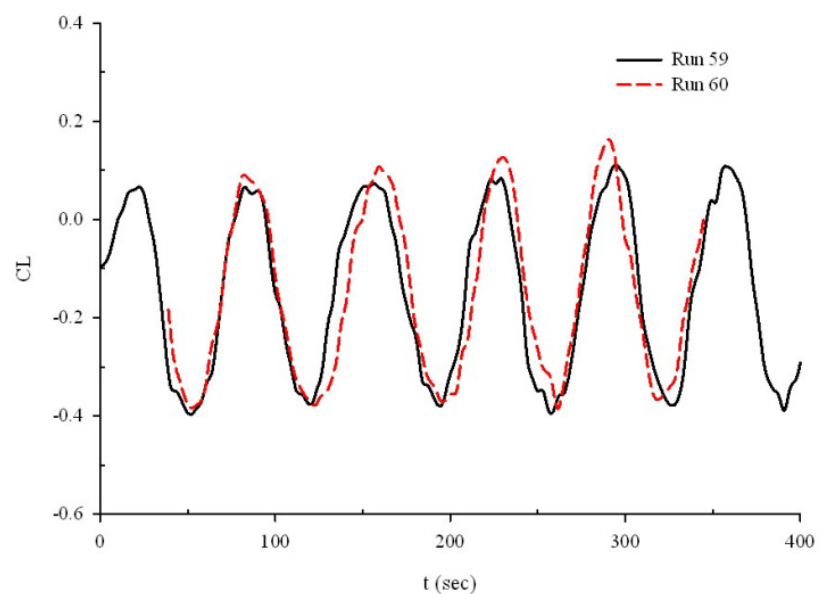

(a)

Figure 10(a).-The time history of lift coefficient $\left(C_{L}\right)$ measurement for 5-27-10 Run 59 and 60.

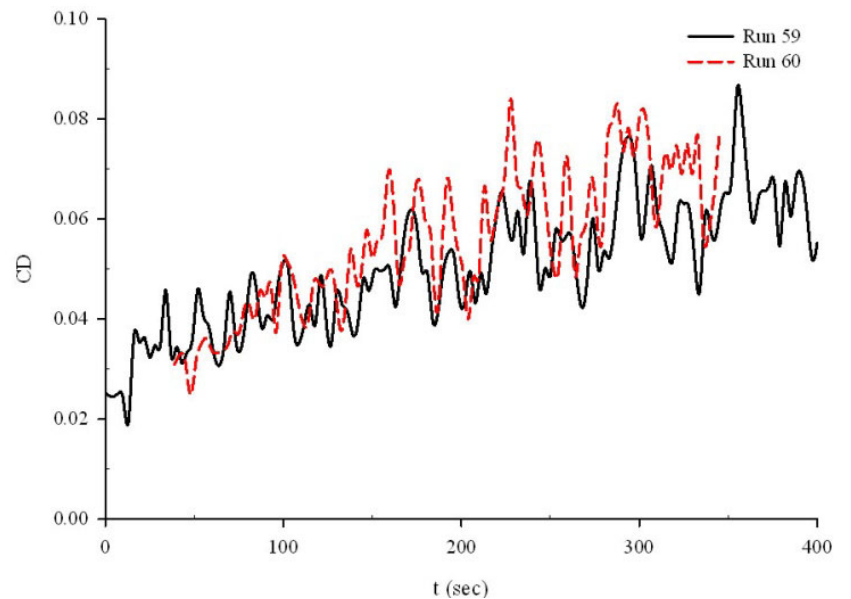

(b)

Figure $10(\mathrm{~b})$.- - The time history of drag coefficient $\left(C_{D}\right)$ measurement for 5-27-10 Run 59 and 60. 


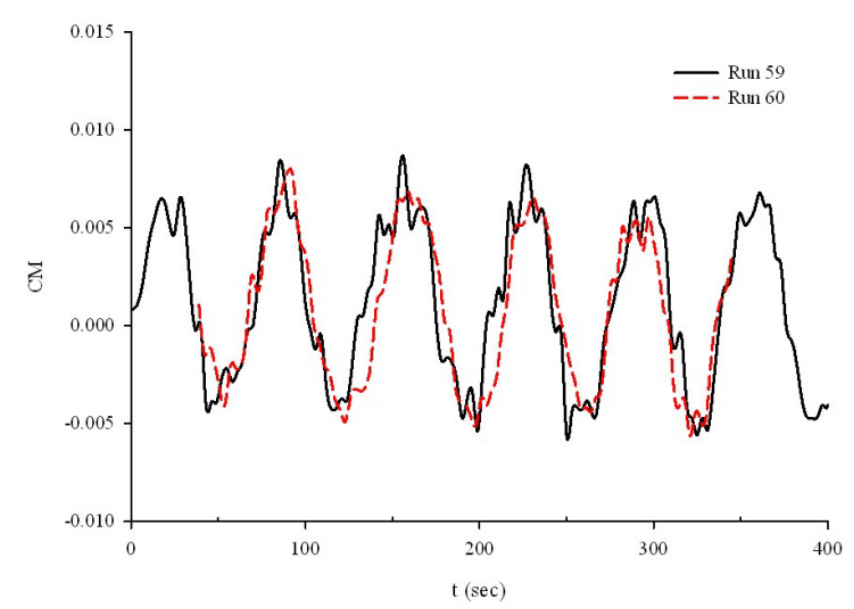

Figure 11.-The time history of pitching-moment coefficient $\left(C_{M}\right)$ measurement for 5-27-10 Run 59 and 60.
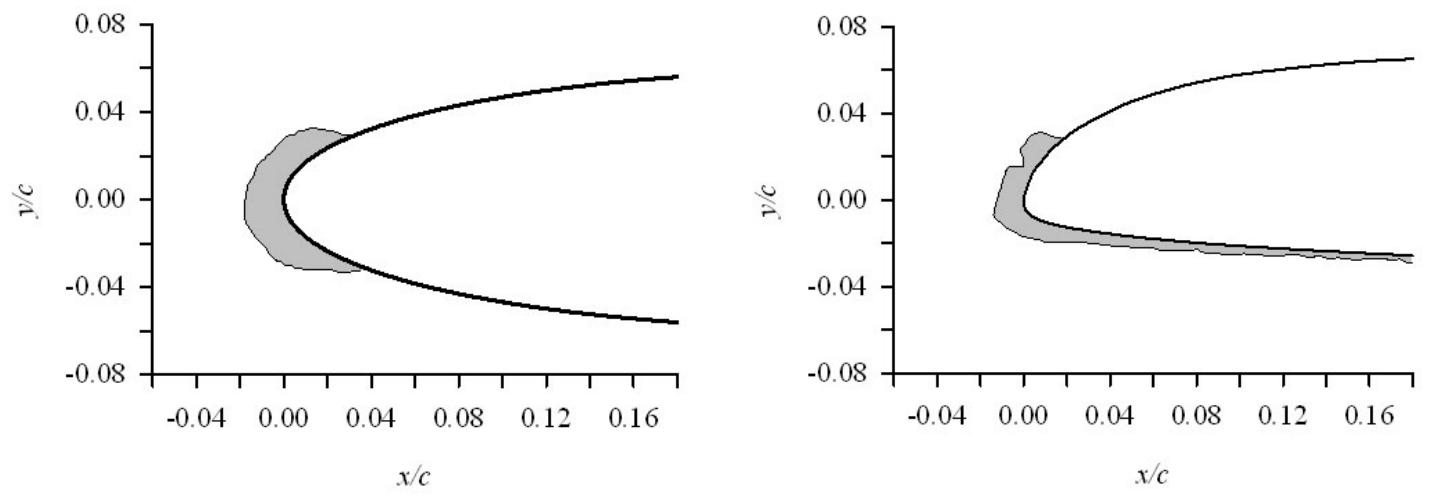

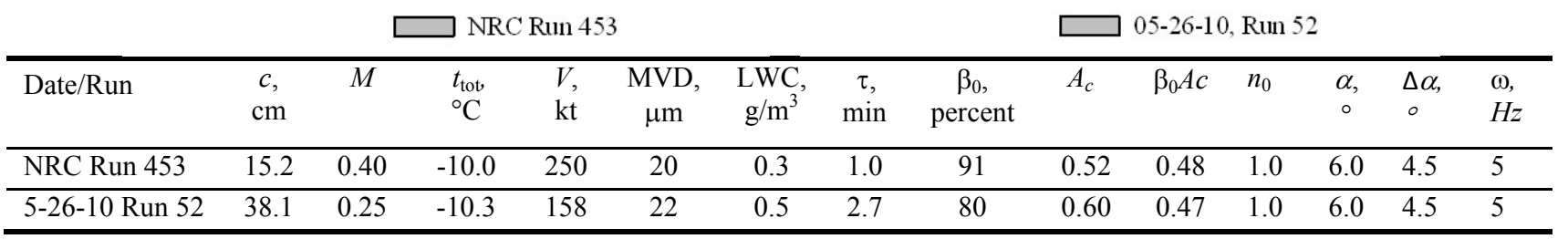

Figure 12.-Size and condition scaling for NRC Run 453.

\section{Summary/Conclusions}

Two rotor airfoil icing tests were performed in the NASA Glenn Icing Research Tunnel, and some size and condition scaling results from airfoil models at fixed angle of attack and dynamic pitching motion were presented in this study. Evidence from ice shape comparison for NACA 0012 airfoils showed that the ability to simulate a reference ice shape by size scaling was not affected by the angle of attack in the range tested. Also limited evidence from ice shape and load measurement comparison for a Sikorsky SC2110 airfoil suggested that the ability to simulate a reference ice shape by size and condition scaling was not affected by the dynamic pitching motion in the range tested.

Good ice shape scaling was achieved by matching scale and reference values of the parameters $\beta_{0}, A_{c}$, $n_{0}$, and $\mathrm{We}_{L}$ for NACA 0012 airfoils with angle of attack up to $7^{\circ}$. Model size ratio was 2.6:1 and freezing fractions covered the range from 0.3 to 0.5 . The present SLD reference tests were made with velocities of $100 \mathrm{kt}$, and these conclusions may not be valid for higher velocities. Additional testing in the IRT is needed to document the limiting conditions for such application to improve the current scaling knowledge and capability for rotorcraft icing. 
From the load measurement of two similar ice shapes obtained from condition scaling it was shown that the $C_{L}$ and $C_{M}$ of reference and scale ice shape would be similar if the main ice shape and large scale feather features were kept via the scaling calculation. However for the $C_{D}$ similarity, the smaller reference ice shape features (in the order of the boundary layer scale) would also have to be captured by the scale ice shape via the scaling.

Developing an experimental method for rotorcraft scaling will help industry users (domestic or international) to standardize the scaling test procedure as well as its credibility as a means of compliance for certification. As a result it will shorten the time and resource required for the certification process. It will also enhance NASA's own core capability to conduct relevant icing test in an icing research tunnel (i.e., its ability to simulate the actual in-flight icing condition and its effects) as well as increase our knowledge of relevant icing physics involved.

\section{References}

1. Anderson, D.N., "Manual of Scaling Methods," NASA/CR-2004-212875, March 2004.

2. Anderson, D.N. and Tsao, J.C., "Ice Shape Scaling for Aircraft in SLD Conditions," NASA/CR2008-215302 and DOT/FAA/AR-07/55, September 2008.

3. "Rotor Blade Electrothermal Ice Protection Design Considerations," SAE Aerospace Information Report 1667, Rev. A, September 2002.

4. Flemming, R., Britton, R., and Bond, T., "Role of Wind Tunnels and Computer Codes in the Certification and Qualification of Rotorcraft for Flight in Forecast Icing," NASA TM 106747, October 1994.

5. Tsao, J.C. and Kreeger, R.E., "Evaluation of Scaling Methods for Rotorcraft Icing," AHS Forum 65, May 27-29, 2009 and NASA/TM-2010-215801, March 2010.

6. Flemming, R.J. and Lednicer, D.A., "High Speed Ice Accretion on Rotorcraft Airfoils," NASA Contractor Report 3910, August 1985.

7. Langmuir, I. and Blodgett, K.B.: "A Mathematical Investigation of Water Droplet Trajectories," Army Air Forces Technical Report No. 5418, February 1946.

8. Messinger, B.L., "Equilibrium Temperature of an Unheated Icing Surface as a Function of Airspeed," J. Aeron. Sci., vol. 20 no. 1, January 1953, pp 29-42.

9. Tribus, Myron, Young, G.B.W. and Boelter, L.M.K., "Analysis of Heat Transfer Over a Small Cylinder in Icing Conditions on Mount Washington," Trans. ASME, vol. 70, November 1948, pp 971-976.

10. Ruff, G.A., "Analysis and Verification of the Icing Scaling Equations," AEDC-TR-85-30, vol 1 (rev), March 1986.

11. Charpin, F. and Fasso, G., "Essais de givrage dans la grande soufflerie de Modane sur maquettes a echelle grandeur et echelle reduite," L'Aeronautique et l'Astronautique, no. 38, 1972, pp 23-31. English translation published as "Icing Testing in the Large Modane Wind-Tunnel on Full-Scale and Reduced Scale Models," NASA TM-75373, March 1979.

12. Feo, A., "Similarity of Water Film Weber Number and Film Thickness in Icing Scaling," AE/TNO/4420/264/INTA/01, Instituto Nacional de Técnica Aeroespacial, October 2001.

13. Olsen, W. and Newton, J., "Experimental and Analytical Evaluation of Existing Icing Scaling Laws," unpublished draft of NASA Technical Memorandum, 1986.

14. Ide, Robert F. and Oldenburg, John R., "Icing Cloud Calibration of the NASA Glenn Icing Research Tunnel," AIAA-2001-0234, January 2001.

15. SigmaScan Pro, image-processing software, ver. 5.0, Systat Software, Inc., Point Richmond, CA. 


\begin{tabular}{|c|c|c|}
\hline \multicolumn{2}{|c|}{ REPORT DOCUMENTATION PAGE } & $\begin{array}{l}\text { Form Approved } \\
\text { OMB No. 0704-0188 }\end{array}$ \\
\hline \multicolumn{3}{|c|}{ 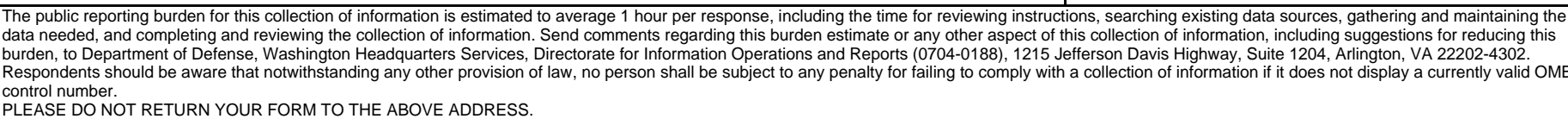 } \\
\hline $\begin{array}{l}\text { 1. REPORT DATE (DD-MM-YYYY) } \\
01-05-2012\end{array}$ & $\begin{array}{l}\text { 2. REPORT TYPE } \\
\text { Technical Memorandum }\end{array}$ & 3. DATES COVERED (From - To) \\
\hline \multirow{3}{*}{\multicolumn{2}{|c|}{$\begin{array}{l}\text { 4. TITLE AND SUBTITLE } \\
\text { Further Evaluation of Scaling Methods for Rotorcraft Icing }\end{array}$}} & 5a. CONTRACT NUMBER \\
\hline & & 5b. GRANT NUMBER \\
\hline & & 5c. PROGRAM ELEMENT NUMBER \\
\hline \multirow{3}{*}{\multicolumn{2}{|c|}{$\begin{array}{l}\text { 6. AUTHOR(S) } \\
\text { Tsao, Jen-Ching; Kreeger, Richard, E. }\end{array}$}} & 5d. PROJECT NUMBER \\
\hline & & 5e. TASK NUMBER \\
\hline & & $\begin{array}{l}\text { 5f. WORK UNIT NUMBER } \\
\text { WBS 877868.02.07.03.03.01 }\end{array}$ \\
\hline \multicolumn{2}{|c|}{$\begin{array}{l}\text { 7. PERFORMING ORGANIZATION NAME(S) AND ADDRESS(ES) } \\
\text { National Aeronautics and Space Administration } \\
\text { John H. Glenn Research Center at Lewis Field } \\
\text { Cleveland, Ohio 44135-3191 }\end{array}$} & $\begin{array}{l}\text { 8. PERFORMING ORGANIZATION } \\
\text { REPORT NUMBER } \\
\text { E-18089 }\end{array}$ \\
\hline \multirow{2}{*}{\multicolumn{2}{|c|}{$\begin{array}{l}\text { 9. SPONSORING/MONITORING AGENCY NAME(S) AND ADDRESS(ES) } \\
\text { National Aeronautics and Space Administration } \\
\text { Washington, DC 20546-0001 }\end{array}$}} & $\begin{array}{l}\text { 10. SPONSORING/MONITOR'S } \\
\text { ACRONYM(S) } \\
\text { NASA }\end{array}$ \\
\hline & & $\begin{array}{l}\text { 11. SPONSORING/MONITORING } \\
\text { REPORT NUMBER } \\
\text { NASA/TM-2012-217418 }\end{array}$ \\
\hline \multicolumn{3}{|c|}{$\begin{array}{l}\text { 12. DISTRIBUTION/AVAILABILITY STATEMENT } \\
\text { Unclassified-Unlimited } \\
\text { Subject Category: } 02 \\
\text { Available electronically at http://www.sti.nasa.gov } \\
\text { This publication is available from the NASA Center for AeroSpace Information, 443-757-5802 }\end{array}$} \\
\hline
\end{tabular}

\section{SUPPLEMENTARY NOTES}

\section{ABSTRACT}

The paper will present experimental results from two recent icing tests in the NASA Glenn Icing Research Tunnel (IRT). The first test, conducted in February 2009, was to evaluate the current recommended scaling methods for fixed wing on representative rotor airfoils at fixed angle of attack. For this test, scaling was based on the modified Ruff method with scale velocity determined by constant Weber number and water film Weber number. Models were un-swept NACA 0012 wing sections. The reference model had a chord of $91.4 \mathrm{~cm}$ and scale model had a chord of $35.6 \mathrm{~cm}$. Reference tests were conducted with velocity of $100 \mathrm{kt}(52 \mathrm{~m} / \mathrm{s})$, droplet medium volume diameter (MVD) $195 \mu \mathrm{m}$, and stagnation-point freezing fractions of 0.3 and 0.5 at angle of attack of $5^{\circ}$ and $7^{\circ}$. It was shown that good ice shape scaling was achieved with constant Weber number for NACA 0012 airfoils with angle of attack up to $7^{\circ}$. The second test, completed in May 2010, was primarily focused on obtaining transient and steady-state iced aerodynamics, ice accretion and shedding, and thermal icing validation data from an oscillating airfoil section over some selected ranges of icing conditions and blade assembly operational configurations. The model used was a 38.1-cm chord Sikorsky SC2110 airfoil section installed on an airfoil test apparatus with oscillating capability in the IRT. For two test conditions, size and condition scaling were performed. It was shown that good ice shape scaling was achieved for SC2110 airfoil at dynamic pitching motion. The data obtained will be applicable for future main rotor blade and tail rotor blade applications.

\section{SUBJECT TERMS}

Icing; Scaling; Rotorcraft

\begin{tabular}{|c|c|c|c|c|c|}
\hline \multicolumn{3}{|c|}{ 16. SECURITY CLASSIFICATION OF: } & \multirow{2}{*}{$\begin{array}{l}\text { 17. LIMITATION OF } \\
\text { ABSTRACT } \\
\text { UU }\end{array}$} & \multirow{2}{*}{$\begin{array}{l}\text { 18. NUMBER } \\
\text { OF } \\
\text { PAGES } \\
23\end{array}$} & \multirow{2}{*}{$\begin{array}{l}\text { 19a. NAME OF RESPONSIBLE PERSON } \\
\text { STI Help Desk (email:help@sti.nasa.gov) } \\
\text { 19b. TELEPHONE NUMBER (include area code) } \\
\text { 443-757-5802 }\end{array}$} \\
\hline $\begin{array}{l}\text { a. REPORT } \\
\text { U }\end{array}$ & $\begin{array}{l}\text { b. ABSTRACT } \\
\mathrm{U}\end{array}$ & $\begin{array}{l}\text { c. THIS } \\
\text { PAGE } \\
\text { U }\end{array}$ & & & \\
\hline
\end{tabular}


